This item was submitted to Loughborough's Research Repository by the author.

Items in Figshare are protected by copyright, with all rights reserved, unless otherwise indicated.

\title{
Guy Aldred: bridging the gap between Marxism and Anarchism
}

PLEASE CITE THE PUBLISHED VERSION

http://dx.doi.org/10.1080/13569317.2011.540950

PUBLISHER

(C) Routledge (Taylor \& Francis)

VERSION

AM (Accepted Manuscript)

LICENCE

CC BY-NC-ND 4.0

REPOSITORY RECORD

Kinna, Ruth. 2019. "Guy Aldred: Bridging the Gap Between Marxism and Anarchism”. figshare. https://hdl.handle.net/2134/8127. 
This item was submitted to Loughborough's Institutional Repository (https://dspace.lboro.ac.uk/) by the author and is made available under the following Creative Commons Licence conditions.

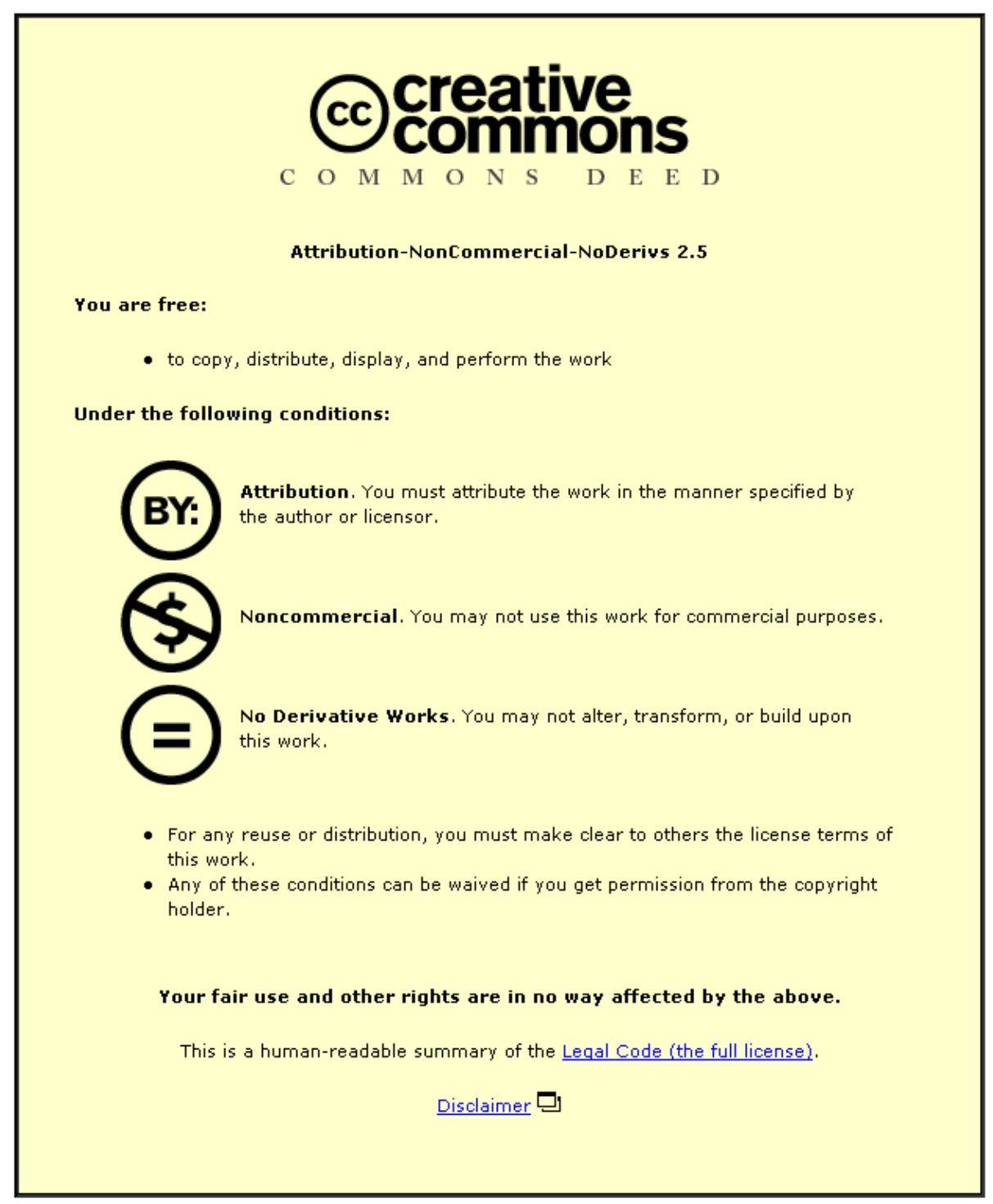

For the full text of this licence, please go to: http://creativecommons.org/licenses/by-nc-nd/2.5/ 


\title{
Guy Aldred: Bridging the Gap Between Marxism and Anarchism
}

\begin{abstract}
This article examines the political thought of the socialist campaigner, Guy Aldred, in order to reflect on divisions between anarchism and social democracy in the late nineteenth and early twentieth centuries. Aldred's thought drew on a diverse range of ideas and he labelled this rich synthesis communism. Believing that his position captured the best of Marxist and anarchist traditions, he argued that socialist factionalism was based on a distortion of Marx's work and that the relationship between Marxism and anarchism was properly understood as one between the head and heart of the movement. His claim not only subsumed the anarchist critique of social democracy into Marxism, it also relied on a system of classification which undercut the creative tensions in his political thinking.
\end{abstract}

Some historical figures are deservedly neglected but Guy Aldred is not one of them. His influence, thought not extensive, is important. ${ }^{1}$ Although Aldred is a problematic figure in many ways, his attempt to carve a niche for himself as a non-aligned revolutionary socialist in the early twentieth century, was significant. What Nicholas Walter called his 'main problem' - that 'he belonged to no viable organisation, ${ }^{2}$ - is precisely what sheds important light on the nature of socialist factionalism, illuminating the difficulty of bridging the gap between Marxism and anarchism. Moreover, Aldred's defence of individualism and the centrality of his activism provide a useful vantage point from which to observe contemporary divisions within anarchism. For all these reasons Aldred deserves to be rescued from obscurity. In this article, after a brief biographical sketch, I analyse his political thought and the development of his communism, placing it in the context of the important dispute about federalism and individualism which divided Marxists and anarchists in the years leading up to the First World War. 


\section{Aldred's political development}

Aldred was born in London in 1886 and died in Glasgow in 1963, just before his seventy-seventh birthday. By the time of this death some of his would-be comrades thought that he was living in something of a time-warp. Albert Meltzer left this portrait:

He was an old-fashioned socialist agitator, who struck to Victoriantype knickerbockers ... rather than trousers, and who early in life conceived his career as a professional street-corner speaker. It is something now inconceivable, and reliance on collections ... made for a hard struggle with poverty for most of his days $\ldots{ }^{3}$

The trajectory of Aldred's career was also rather Victorian. He began as an evangelical Christian, encouraged by his anti-militarist and freethinking maternal grandfather to study and read widely. At school he joined the AntiNicotine League to become a 'recruiting agent' for the Band of Hope and Total Abstinence Movement. ${ }^{4}$ In 1902 he extended his activities to anti-war propaganda, adopting the title of the 'Holloway boy preacher' of the Christian Social Mission, an evangelical organisation he founded with John Willoughby Masters, the self-styled 'Lyrical Gospel Herald'. ${ }^{5}$ However, Aldred's evangelism did not prevent him from challenging Victorian moral codes. In 1907 he met Rose Witcop. Flouting convention they practiced the principle of free love, marrying in 1926, long after the experiment had collapsed, only because she was threatened with deportation. ${ }^{6}$ Against the moralising tone of Aldred's writings, Rose represents perhaps the most refreshing and libertarian aspect of his life. The younger sister of Milly Witcop (the life-long companion 
of Rudolf Rocker) she was a committed feminist and at no little cost put up with the social stigma of being a single mother. Swept along by ideas of social revolution, Aldred campaigned with her to spread information about contraception and the evils of bourgeois marriage law and was particularly concerned to tie socialism to women's emancipation. Yet there were limits to his libertarianism: whilst both rejected the women's suffrage campaign as reformist Aldred, unlike Rose, had a natural inclination to monogamy and cherished an ideal of chaste socialist partnership. ${ }^{7}$ Moreover, he combined the spirit of social experimentation with a disturbing sense of his own infallibility.

John Caldwell, Aldred's biographer, described him as 'a man of true genius who vigorously and untiringly devoted his life to the enlightenment and uplifting of the people, and to the bringing about of socialism'. ${ }^{8}$ For those less devoted, his enthusiasms could wear thin. His pun on his surname - 'the man they all dread' - aptly pointed to his troubled relationship with his comrades. He joined the Social Democratic Federation in March 1905 but resigned less than two years later. Gravitating towards the anarchist Freedom group he got on well with some anarchists and greatly admired Malatesta ${ }^{9}$ but described the majority as a feckless bunch. By 1907 he had severed his ties with both wings of the socialist movement and started to call himself a communist, a term which was still little used at the time. In this, he was inspired by the example of William Morris ${ }^{10}$ who, he said, had meant it to describe 'world harmony, social love, service and commonweal'. ${ }^{11}$ While Aldred's temperament was hardly in tune with all these ideals, he shared the vision of socialism they evoked. 
The principles on which he grounded his actions grew from his strong need to find purpose in life. Aldred described his intellectual development as the 'growth in freedom' of his own mind but his account actually suggests that it involved the discovery of an existing tendency as much as a gradual enlightenment. His story is the development of an 'inward allegiance'; of a truth seeker, looking for 'a philosophy that was progressive, yet definite and certain'. ${ }^{12}$ At its heart was an idiosyncratic religious commitment.

Even at the height of his evangelism, Aldred never espoused an orthdox Christian faith: his study of world religions, his friendship with the theist Charles Voysey and his attraction to Thomas Huxley led him from Anglicanism to atheism, without forcing any open rupture. His mature view was that it was possible to question the existence of a deity and the historical existence of Jesus but remain a Christian: the fact of Jesus' existence was less important than his teachings; and since God was an idea that came from within the minds of men it was important to distinguish faith in the possibility of living a Christian life from belief in a divine being. The former was a positive, motivating force but the latter encouraged dull submission. Indeed, associating the belief in God with theology, miracles and superstition, Aldred declared: 'God never did, never will and never can exist'. ${ }^{13}$

Initially, Aldred's religiosity was romantic and conservative. Later he combined romanticism with radical dissent. Having taken to 'heresy with all sincerity', ${ }^{14}$ as he subsequently put it, he gave up Toryism in favour of materialist free thought and so descended from 'the world of cloudland to that of matter, of social life and struggle'. ${ }^{15}$ In all this, religion remained a powerful 
influence and it lent his socialism a visionary, crusading and dissenting character.

Aldred described his vision of socialism as the realisation of equality, mutual aid, freedom, justice and social peace, in short: 'the kingdom of heaven on earth into which the rich cannot enter'. ${ }^{16}$ Unlike Morris, Aldred was not interested in describing this picture and he tended instead to think in terms of a process of ethical development. As he put it: 'the drawing out, in the sense of cultivation, of the inspirational part of man's character, whereby men are led to forget the limitations of their material environments in their realisation of their oneness with all phenomena'. ${ }^{17}$ Vision, he argued, was nothing without the possibility of achievement. His view lent his socialism a purposive, crusading character. Here, too, religion was the inspiration. Christianity, he argued, 'cannot be shut up in a few lines of abstract and ridiculous creed'. It is 'a declaration of fire, light, freedom ...'18 To make it real, it needed enthusiasts like him - preachers - who were not only prepared to spread the Word, but also put up with the 'scorn and abuse' that genuine commitment to cause was likely to bring. Aldred's grandfather had once asked him to reflect on the 'lofty heroism, the enduring patience, the unselfish love, and the perfect sweetness in service' that Shelley's 'tragic story of Prometheus inspired'. ${ }^{19}$ Aldred did, and found in it a 'central ethic of brotherhood and service'. ${ }^{20}$ To adopt this ethic was to engage in action. Service, he remarked, 'makes life not a worship but a struggle' because it was driven by 'peace of conscience' and 'unyielding martyrdom'. ${ }^{21}$ To show that these demands could be met by ordinary people, Aldred devoted much of his writing to recounting the lives and experiences of virtuous fighters - from the 
Marian martyrs to the nameless conscientious objectors with whom he campaigned in two World Wars. Most were unknown and they came from different classes and social backgrounds. Tom Dowd, the subject of one of Aldred's essays, was a common criminal. The common bond he identified in them was their rebellious character and willingness to endure hardship for the sake of principle.

Aldred's celebration of socialist service was combined with a third element: dissent. As a self-styled heretic Aldred was also an ethical voluntarist who abhorred the idea of coercion. It was one thing to point out individuals' errors, quite another to force them down the road to redemption. Smokers and drinkers might be told that their 'habits are injurious' but, he insisted, his own abstinence 'had no bigotry' about it. ${ }^{22}$ To support this position, he identified reason as his 'supreme guide', meaning not what he called the 'Freethinkers' abstract "reason,"' but individual conscience. ${ }^{23} \mathrm{He}$ elaborated his idea through Descartes but claimed that the philosopher had 'never understood his own maxim' or its radical implications. "Cogito, ergo sum" for Aldred was a 'definition of the ... unchallengeable integrity of the individual.' No man who had 'sufficient courage to accept as the keynote of his life ... "I think, therefore I am"' could ever be 'a slave ... [or] victimised or imposed upon by any system of authority or oppression‘ ${ }^{24}$ This conviction became a guiding principle which he eagerly applied to adults and children alike. For example, he resigned from the Social Democratic Federation because he thought the party's support for Socialist Sunday Schools was as an attempt to impose 'Marxism upon the child's mind'. ${ }^{25}$ Though he believed it was his duty to effect social transformation, he claimed to rely solely on 
'example and personal integrity ... in the power of moral suasion and very simple, very direct propaganda'. ${ }^{26}$ Having cast himself in the role of 'Minister of the Gospel of Revolt' he expected others to do likewise: '[e]ach one of us should, and must, belong to ourselves ${ }^{, 27}$.

\section{Socialist Theory}

Drawing on these visionary, crusading and dissenting principles, Aldred developed a form of socialism that was both radically anti-statist and evolutionary.

Aldred's anti-statism recalled Tom Paine who, he claimed, had been the first to argue that 'the abolition of formal government' was the 'beginning of true association'. ${ }^{28}$ He rejected the state on both functional and organisational grounds. The state's function was to fleece 'or blackmail the capitalist class' in order to provide 'a standing army, navy, judicial bench, etc. ${ }^{29}$ All states were instruments of class exploitation and the constitution of government was irrelevant to this function. The difference between 'the crowned Monarch in England, the sceptred Emperor in German [sic] and the uncrowned President of the United States' was only one of form: in each case, government was a reflection of class power and its character in the state was always the same. ${ }^{30}$

In its organisation, the state's 'bureaucratic institution' supported 'tyranny and expertism'. These were not merely facets of economic exploitation. Even assuming that the basic precondition for communism 'social ownership based on social production and distribution' - were met, 
socialists would still need to address the organisation of the state's 'historically evolved administrative function'. The abandonment of the bourgeois state's legislative and judicial systems would not lessen this necessity. ${ }^{31}$ Aldred warned here that 'the representatives of administration' might 'so control industry and education as to become the monopolisers of its advantage'. ${ }^{32}$ Such socialism would merely perpetuate class rule, grounding advantage in position rather than ownership.

Whilst Aldred's critique left open the possibility that socialists might detach the principle of government from the function of the state his concerns about 'expertism' pointed to a form of decision-making that would look very different to existing governmental systems. Indeed, Aldred argued that that the representative institutions of parliamentary government could never provide a model. Representation meant majoritarianism and it was simply a cover for coercion. At its heart was the fallacy that decision-makers could speak on behalf of others. He found a working alternative model in industrial unionism and expressed broad sympathy with the Industrial Workers of the World (I.W.W) and, later, with the Spanish CNT. However Aldred did not consider himself a syndicalist. Having 'no faith in the majority, less unbelief in the minority, and most reliance in the individual ${ }^{, 33}$ he was suspicious of the scale of syndicalist organisation and he rejected the idea of 'one big union' touted in the early decades of the twentieth century. Moreover, whilst he preferred small workshop units to protect against reformism ${ }^{34}$ he believed that even this form of association still fell short of meeting his religious, visionary needs. ${ }^{35}$ Its followers understood that socialism 'applies a materialistic analysis to society' but wrongly 'ignored ... the need for Idealism'. Socialism 
'involves love'; it 'is harmony', Aldred declared. ${ }^{36}$ Again turning to Morris for inspiration he argued: 'There can be no talk of working-class political power ... There must be an end of political power if the workers are to be free'. ${ }^{37}$

Aldred's faith in the possibility of socialism rested on a specific concept of change. This fused an instinctive Hegelianism with a broad commitment to historical materialism. Aldred's general view was informed by a feeling 'that belief in change represented the stream of life: yet the change must express a stability of purpose, have direction, and not be so much drifting'. ${ }^{38}$ With his discovery of economics and sociology, this intuition led him quickly to conclude that 'political changes have occurred "simultaneously with economic changes in society"'. 39 At the same time Aldred sought to go beyond materialism and combine his view of change with a concept of ethical development. Here he borrowed from both Kropotkin and Nietzsche.

Aldred claimed that his interest in evolution was inspired by T.H. Huxley's Romanes lecture of 1893, the lecture which also influenced the development of Kropotkin's theory of mutual aid. However, Aldred's repeated references to Huxley's work were taken from an earlier essay, 'Government: Anarchy or Regimentation'. Aldred appears to have misunderstood Huxley's essay as an endorsement of anarchy, when in fact it presented a critique. ${ }^{40}$ He added to the confusion by misinterpreting Kropotkin. Kropotkin had taken issue with Huxley's claim that the natural world was 'red in tooth and claw' and argued that the social ethic which Huxley associated with civilisation and the struggle against nature was in reality a factor of evolution which might be realised in anarchy. Ignoring Kropotkin's criticisms of Huxley's characterisation of nature, Aldred focused on Huxley's treatment of 'ethical 
fitness'. As a result, he wrongly suggested that Huxley's work lent scientific support to the idea of anarchy (and indeed, to Kropotkin's idea of anarchy) and that he subscribed to an evolutionary theory which grounded ethics in nature. $^{41}$ Aldred agreed with Kropotkin that the expression of socialist ethics was environmentally conditioned and he shared Kropotkin's view that altruistic behaviours were motivated by egoism, remarking that '[w]e incline to abolish suffering because pain to others occasions agony for ourselves'. ${ }^{42}$ However, his conception of environment and ethics was different. Aldred linked socialist ethics to a process through which 'the individual ability and power to survive' would be reconciled with 'the evolution of the social instinct and the desire to serve'; a process of harmonisation leading individuals to perform certain functions in the social organism. ${ }^{43}$ In contrast Kropotkin argued that mutual aid - the anarchist ethic - was an instinct which supported co-operative behaviours that the environment might encourage or inhibit.

Aldred identified education as the mechanism for evolutionary social practice. His view chimed in with Morris's, particularly the policy of 'making socialists', but it was also tied to his own biography and whereas Morris linked education to moral behaviour, specifically the shift from competitiveness to fellowship, Aldred associated it with revelation and the acquisition of practical skills. Education described both the ability to grasp the truth and the possibility of applying acquired knowledge to redress the injustices that it made plain. John Caldwell described Aldred's conception as Orwellian: 'In a time of universal deceit, telling the truth is a revolutionary act'. Adding a new twist to Marx's prediction that capitalism would create its own gravediggers, Aldred further located the dynamic for learning in the capitalist system. The 
'capitalist environment' he argued, 'not only favours, but creates the Communist' ${ }^{44}$ In order to feed its need for capable workers, capitalism educated the masses, thus undermining the position of the expert. As Aldred put it: the 'evolution of the capitalistic educational system has prepared a minimum educational basis for the future society to start from, which is founded on an ever-increasing negation of expertism' ${ }^{45}$ The brilliance of this account of educational development was that it underwrote the promise of socialist equality; its weakness, which Aldred seems to have acknowledged, was that the analysis was not entirely persuasive. As if attempting to convince himself of the truth of capitalism's demise, he resorted to defending evolution negatively. The possibility that he might be wrong about learning was simply too horrible to contemplate:

The psychological guarantee against expertism will be found in the contempt with which all men will regard it, and the tendency to excellence of administration will be reposed in the admiration will have for efficiency. Should this possibility still meet with opposition on the ground that such a central directing authority, finding its embodiment in a collective will, would not find legal oppression incongruous with its industrial basis, one can only conclude that either humanity is inherently bad and progress an impossibility, or else that in a system of absolute individualism must humanity's hope lie. ${ }^{46}$

Aldred's individualism was the final plank in his understanding of ethical change. If his original concept had been shaped first by his freethinking background, it was with Nietzsche that Aldred identified as a socialist; but a 
Nietzsche read through a Darwinian lens. Nietzsche took the 'selfpreservation instinct which all recognise as being the first law of nature ... to be the last law of ethics' ${ }^{47}$ In contrast to neo-Darwinians like Spencer, who adopted this law to defend competitive free markets, inequality and servitude, Nietzsche, he argued, used it to provide critique of domination, exploitation and oppression. In the idea of the superman Nietzsche had elaborated an ideal in which individuals '[f]reed from the desire and the economic power to dominate ... would be neither dominator nor dominated'. With each having 'different traits', the lack of officialdom would 'spell freedom, variety, and consequent genius'. ${ }^{48}$ Aldred's reading was idiosyncratic but his attraction to Nietzsche tapped into the important avant garde trends that developed within anarchism in the period leading up to 1914. Emma Goldman's anarchism drew on similar influences. Alfred Orage's introductions to Nietzsche appeared in 1904-07 and although Aldred was a contributor to Dora Marsden's increasingly Stirnerite $\underline{\text { New Freewoman rather than Orage's New }}$ Age,${ }^{49}$ his claim that Nietzsche 'realised that Socialism must inevitably be identical with absolute individual freedom' was uncontroversial in both of these circles. ${ }^{50}$ Aldred's effort to inject a religious sensibility into Nietzsche's work was more unusual, for even though Tolstoy's work encouraged some to explore the possibilities of a Nietzschean Christian anarchism, Aldred's interpretation was firmly rooted in the religion of his youth. On his account, Nietzsche was a visionary and a 'herald of revolt' who stood in the tradition of the heretical martyrs, dissenters and conscientious objectors he so admired.

To summarise: Aldred's communism was predicated on an idea of dialectical development in which class struggle, capitalist collapse and 
economic change, together with enlightenment and knowledge, would give rise to the expression of natural sociability and the realisation of individual freedom in a condition of statelessness. His political theory drew on an impressively wide range of influences and even though his interpretations are sometimes problematic his attempt to combine them sheds interesting light on the currents of socialist thought. However, Aldred is interesting not just because of the way he synthesised these currents but also because of the ideological terms he used to describe his position. The way in which Aldred situated himself in the political spectrum raises some enduring questions about the status of Marxist theory in socialist thought and, as I will now argue, the distinctive contribution to revolutionary socialism made by anarchism.

\section{Communism, Anarchism and Marxism}

After cutting his ties with the Freedom circle in 1907 Aldred was involved with a number of groups: the Industrial Union of Direct Action, the Communist Propaganda Group, the Glasgow Communist Group and, between 1921-34, the Anti-Parliamentary Communist Federation. ${ }^{51}$ Although the Glasgow Communist Group co-operated closely with the longer-established Anarchist Group, all these groups were non-aligned. The success of the Bolshevik revolution in 1917 and the subsequent identification of communism with the Soviet system, or what Aldred called 'dictatorship and totalitarian oppression, assassination and darkness ${ }^{, 52}$ complicated the parameters of Aldred's early non-alignment. But in the period leading up to 1914, these were marked by the ideological poles of social democracy and anarchism. In this context, nonalignment did not indicate neutrality or aloofness. On the contrary, Aldred 
broadly accepted the anarchist critique of social democracy and his decision to label himself 'communist' symbolised his belief that the gap between the two wings of the socialist movement could be bridged. Outlining the debate between social democrats and anarchists - which were well rehearsed in the socialist press - reveals the space that Aldred sought to occupy and helps explain how communism brought these two socialist traditions together.

In the ten years before 1907, when Aldred defined his position as an independent, relations between social democrats and anarchists had soured appreciably. Some historians trace the roots of the division to the 1871 dispute between Bakunin and Marx in the First International. Others go even further back and suggest that it was Marx's falling-out with Proudhon some twenty years before which marked the start of the split. ${ }^{53}$ As G.D.H. Cole notes, the causes of the disagreement were both more proximate and more dramatic. The key event was the 'affaire Millerand' of 1889, which brought into sharp focus the question of whether socialists could legitimately participate in bourgeois institutions. Its immediate trigger was the resolution of the 1893 Zurich Congress of the Second International, which committed working class organisations to political action and resulted three years later in what Eduard Marx-Aveling celebrated as the final 'casting out of the anarchists' in London. ${ }^{54}$ Aveling's remark that the expulsion of the anarchists had been 'well worth working three years for' shows how tensions had been building. ${ }^{55}$ Nevertheless the exclusion of the anarchists caught many participants by surprise. So-called non-parliamentary socialists - those who had refused to align themselves either to anarchism or social democracy were appalled to see how a policy difference was made into a test of 
ideological commitment. ${ }^{56}$ The attempt to narrow the definition of socialism to mean social democracy alone and to outlaw anarchism was also fiercely criticised. ${ }^{57}$ Critics like Kier Hardie condemned this reduction and ridiculed the result as 'cast-iron socialism', a reference, perhaps, to its seeming Prussian inflexibility. ${ }^{58}$ Proponents of parliamentary action also recognised the significance of the division. Justice, the paper of the Social Democratic Federation, argued that forcing non-parliamentary socialists to give up their 'untenable ... position' and finally 'choose sides' was a positive result of the decision. ${ }^{59}$ The extent of the polarization was also indicated by the intolerant language adopted. Justice no longer treated anarchism as a strain of socialism; nor did it merely distinguish anarchism from socialism - it now identified anarchists as the enemies of social democracy. In August 1896 one correspondent to Justice expressed his disappointment at finding the 'language of the capitalist press repeated in a Socialist journal'. He complained that the editors had been wrong to describe anarchist tactics as 'blackleg and blackguardly'. 60

In the aftermath of the 1896 London Congress, differences between social democrats and anarchists touched on a number of core questions: the relationship of socialism to science and utopianism; the nature of socialist organisation and the relationship between capitalism, socialist transformation and modernisation; the process of revolutionary change and the use of terrorist methods. For Aldred two ideas were of particular importance: federalism and individualism. Recalling his initial attraction to anarchism, he wrote: 
It must not be concluded that I was any less a Socialist because I called myself an Anarchist. I definitely accepted the principle of Federalism as opposed to Centralism, and I did not believe that Individualism was opposed either to Socialism or to Democracy. On the contrary, I believed that Individualism must be asserted and defended in the interests of Socialism and as a cardinal principle of Democracy'. ${ }^{61}$

Justice treated both principles with suspicion because, as Aldred observed, it saw them as synonyms for anarchism. Individualism in particular came under sustained and systematic critique. In the words of one correspondent to Justice, it ran counter to 'organisation and true policy' and 'agreement on a practical programme' which genuine socialists recognised. ${ }^{62}$ Because they were individualists, he continued, anarchists rejected authority and, indeed, all forms of association. They refused '[c]ombination, organisation [and] unity' and, believed that 'these words imply government of some kind hurtful to the ego'. ${ }^{63}$ Justice recognised that individualism was contested anarchist circles and that 'anarcho-communists' typically rejected individualist positions. Yet the paper argued that whatever prefix they might attach to their name all anarchists defended the absolute interests of the individual. That made co-operation impossible. It gave what it claimed was the essence of the anarchist view:

The Anarchist, with all his denunciations of authority, does believe in authority - autocratic authority, the authority which any individual can impose upon any community or assembly, that is, the authority which the Anarchist favours. The authority he does not believe in 
is democratic authority, authority constituted by the will of the community, that is anathema ... to the Anarchist. ${ }^{64}$

In reinforcing this point, leading international theorists of social democracy used Stirner and Nietzsche as Aunt Sallies. ${ }^{65}$ William Liebknecht, for example, identified Stirner as the 'father of modern Anarchism', dismissing 'Bakounin [sic.], Proudhon and the latest day saints of Anarchism' (all influential figures in the European labour movement) as 'mere pigmies' by comparison. ${ }^{66}$ As one contributor to the anarchist paper The Torch noted, the focus on Stirner was a convenient half-truth since it allowed social democrats to forge a link between anarchism and certain forms of laissez-faire capitalism which claimed to take inspiration from his work. ${ }^{67}$ Liebknecht pressed this point:

There is, in fact, nothing in common between Anarchism and Socialism. Anarchism - if it is not altogether a senseless phrase has individualism for its basis; that is, the same principle on which capitalist society rests, and therefore it is essentially reactionary, however hysterical may be its shrieks of revolution. ${ }^{68}$

Nietzsche was used in a similar way. In November 1896 a leader in Justice presented Nietzsche as an advocate of the 'struggle for existence and the survival of the fittest, the rule of force and cunning'. 'Justice, sympathy, self-control, and all the so-called virtues', the paper noted, were for him 'so many arbitrary restraints on the indefeasible right of every man to do what he pleases where and when he can'. Nietzsche's statement of the Anarchist 'theory of the sovereignty of the individual' was unusual for the 'simplicity of nakedness', the leader argued, but in other respects it provided an accurate 
account. $^{69}$ Even writers like E.B. Bax, who was otherwise sensitive to anarchist concerns about liberty and who clearly distinguished anarchist socialism from liberal free-market voluntarism, argued that anarchists treated individual freedom as a 'holy dogma of the abstract freedom or autonomy of the individual at all times and in all cases'. ${ }^{70}$

The social democrats' rejection of anarchist federalism was an elaboration of their critique of individualism and it boiled down to the claim that anarchy was chaotic because anarchists were incapable of recognising, still less working for a common interest. The critique did not imply a rejection of federalism altogether and most social democrats fiercely rejected the term 'state socialism' which anarchists used to describe their position. In fact some, including Bax, called themselves federalists. But they rejected the decentralised communal federalism proposed by the anarchists as unworkable. At issue here was not the possibility of order but its quality. In an examination of the Cecilia community in Palmira, Brazil, one social democrat reported that the anarchists had succeeded in showing 'that men could live without masters and without law'. The community had no 'table of hours' or 'assemblies of the residents'. It had abandoned rules, laws, officials, majority votes and programmes. Moreover, 'all work was voluntary and freely chosen'. Yet for all this abandonment of regulation anarchy was far from paradise. In Cecilia 'public opinion' was 'an unsparing and almost tyrannical force'. Individuals were hardly free; and despite their industriousness, their effort still 'kept them poor'. Because of the failure to devise common rules, anarchy was nasty and cold and, if not brutish, probably short. The important lesson was that 'it is not by individual effort that we shall conquer nature'. No 
'amount of enthusiasm and ability can build up a new civilization, unless there is also subordination, organisation and a regular industrial code'. ${ }^{71}$

The anarchist response to this was to attack parliamentarism and political action. Parliamentarianism, they argued, was based on a misconception of the state. It was politically flawed because it identified the state with government. Even assuming that individual representatives of the working class could resist the psychological appeal of power - which most anarchists doubted - parliamentarism aimed at the achievement of a narrowly political revolution, centred on the seizure of government power, when what was required was a social transformation that would challenge the cultural norms that the state upheld. To make this point Freedom quoted Ibsen. Politicians, he explained, 'only desire partial revolutions, revolutions in externals, in politics. But these are mere trifles. There is only one thing that avails - to revolutionise peoples' minds' ${ }^{72}$

Furthermore, parliamentarism indicated that the social democratic concept of the state was sociologically flawed. Here, anarchists argued that parliamentarianism required the adoption of organisational forms that replicated the very structures they wanted to destroy. As Malatesta put it, the 'gendarmes of Bebel, Liebknecht and Jaurès always remain gendarmes. Whoever controls them will always be able to keep down and massacre the proletariat'. $^{73}$ The historical analysis that supported this view, pioneered by Proudhon and developed by Kropotkin, highlighted the tendency of the state to expand its area of influence in the domestic realm and to militarize the international system. It assumed the existence of a historic free realm into which the state was continuing to expand its competence. Anarchists aimed 
at resisting both this expansion and the new models of organisation bureaucratic, representative and centralised - that it threatened. Their criticism of social democracy was that it was so narrowly preoccupied with questions of ownership that it failed appreciate this equally significant aspect of state development. An analysis published in The Torch suggested that '[w]hat passes for labor organization amongst State socialists, Labor parties, present-day Trade Unions etc. is not an organization of the men but really of the bosses and misleaders to keep their slaves in their slavery'. The author continued:

The governments from Social Democrats to Tories base their socalled organization on forms and majority rules with the result that all the organized are the exploited dupes of the organizers; and are driven here and there like cattle. ${ }^{74}$

Anarchists described the social dynamics of their organisational alternatives differently. Elisée Reclus suggested that anarchy would be constructed on a yearning for co-operation and an overlapping consciousness of purpose: 'a wonderful unity in thoughts, sentiments, and the desire to be free' ${ }^{75}$ By contrast J.A. Andrews argued that individual interest played the crucial organising role, safeguarding individuals from majoritarianism and/or the adoption of programmes for collective action. ${ }^{76}$ But there was consensus that the revolution promised by social democracy would, at best, result in a liberal-radical programme of reform and, at worst, a highly disciplined, rigidly controlled system of oppression. The optimistic view was that 'Socialism "made in Germany"' would bring freedom of worship, universal suffrage, national education, equal rights, public utilities, protective employment 
legislation and an international court to arbitrate international disputes. ${ }^{77}$ Pessimistically, the anarchists' feared that these liberal rights would be tied to a duty to recognise 'as an absolute truth the complete submission of the individual to the State'; and that the achievement of these goals would result in 'State-monopoly in the organisation of the whole economic life of the nation with "obligatory work for all," and "the raising of a working army, especially for agriculture"'. ${ }^{78}$

In these debates Aldred was clearly not on the side of social democracy. His critique of the state dovetailed with Malatesta's; not only was his concern with social revolution anarchistic but his embrace of Nietzsche, his rejection of representation, his interest in non-statist principles of organisation and his fierce defence of the individual all suggest a deep dissatisfaction with social democratic thinkig. Admittedly, Aldred was also an anti-utopia and taking his lead from Daniel De Leon, he dismissed all attempts to consider alternatives to state organisation as 'childish' speculation. ${ }^{79}$ Nevertheless, this difference hardly weighed against his disagreements with the social democrats. Why, then, did Aldred shy away from calling himself an anarchist and prefer communist, instead? The reason is that he thought that anarchism threatened to deepen an unnecessary rift and to conceal the fundamental theoretical unity of revolutionary socialism. Moreover, whereas the anarchists traced the failures of social democracy to Marx, Aldred dismissed social democracy (and later Soviet communism) as a perversion of Marxism and identified Marx as his most significant influence.

The basis for this identification and its implications for Aldred's understanding of anarchism emerge in a review of the relationship between 
Bakunin and Marx which suggests a creative interplay between generations of socialist thinkers: Bakunin, he argued, was 'Proudhon adulterated by Marx and Marx expounded by Proudhon. ${ }^{80}$ At first sight this almost seems to anticipate Daniel Cohn-Bendit's conception of 'leftism' as progressive critical review: Marx against Proudhon, Bakunin against Marx, Makhno against Bolshevism and the student-workers' movement against the 'transformation and development of the Russian Revolution into a bureaucratic counterrevolution, sustained and defended by Communist parties throughout the world'. ${ }^{81}$ Yet the similarity is misleading since unlike Cohn-Bendit, Aldred was not concerned to resist 'ossification'. On the contrary, he wanted to retrieve a particular reading of Marx's thought and inject a concept of Bakuninism into it. Bakunin, he argued, was 'an excellent guide, philosopher and friend to the cause of Communism' when he spoke as a Marxist. ${ }^{82}$

In his keenness to stress Bakunin's significance Aldred note that his writings 'are replete with profound political thought and a clear philosophic conception of history ... ${ }^{83}$ After the rise of Stalin, he reiterated this view. Agreeing wholeheartedly with Bakunin that the problem of the state was ultimately one of command, he argued that the terror of Soviet system arose from to 'a brutal claim to authority almost unbelievable in the name of Communism and Socialism'. More pointedly, returning to the ruins of the First International he argued that Bakunin's theoretical insights anticipated Soviet communism's failings. Bakunin's warning that 'authoritarian Communism ... would persecute like an autocratic or bureaucratic State', he noted, had once been 'viewed with scepticism'. But he had been vindicated by Stalinist practice. The development of the Soviet Union and the Third International 
proved that the 'arguments of yesterday must be acknowledged as being right in their anticipation'. ${ }^{84}$ At times Aldred went as far as to suggest that Marx had played a lesser role in the development of socialism than Bakunin. For example, he argued that in 1847 Marx had sounded 'the call of battle and revolutionary anti-parliamentarism' identifying 'his work with the ideal and endeavour of Bakunin'. ${ }^{85}$ In Bakunin's defence he also openly took issue with Kropotkin's assertion 'that we must measure Bakunin's influence not by his literary legacy ... but by the thought and action he inspired in his immediate disciples'. ${ }^{86}$

Nevertheless, Aldred's claims about Bakunin's theoretical brilliance were fragile and the general tenor of his argument suggested that his assessment of Bakunin was not so far removed from Kropotkin's afterall. More often than not, he identified Marx as the initiator of ideas and Bakunin as his practitioner. He noted whilst Marx was wasting his energy worrying about the anarchism of his sons-in-law, Lafargue and Longuet, 'the Anarchists, inspired by Bakunin ... were putting their hearts and souls into the task of explaining and popularising the work of Marx'. ${ }^{87}$ Central to Aldred's view were Marx's historical writings, particularly The Eighteenth Brumaire and the Civil War in France. These recorded 'as a maturing and matured conviction of Marx, that the Social Republic is not the Parliamentary Republic; that Parliamentarism is ... the counter-revolution'. ${ }^{88}$ Reflecting on the degeneration of Marxism into social democracy, Aldred advanced a similar point:

It has always seemed strange to me that the Marxists, whose economic explanation of politics or the State is correct, should have 
become, in practice, parliamentarians and pretend to believe that parliament controls industry. Proudhon, Bakunin and [Johann] Most, being Anarchists, might be forgiven did they deduce from their hatred of authority, some idea of warring against the State instead of economic conditions. In practice they adopt the correct attitude to wanting to liquidate the State in economic society ... Hence they conclude their propaganda as sound Marxians. ${ }^{, 89}$ For all his originality, Aldred painted Bakunin as 'the word incarnate' not the author of the word. At one with Marx 'in purpose and in aspiration' he was suited to the fulfilment of 'distinct tasks', to serve 'different functions' and 'fitted by temperament to enact a peculiar role .... ${ }^{90}$ He continued: Marx DEFINED the Social Revolution, whilst Bakunin EXPRESSED it. The first stood for the invincible logic of the cause. The second concentrated in his own person its unquenchable spirit. Marx was an impregnable rock of first principles, remorselessly composed of facts ... he was the immovable mountain of the revolution. Bakunin, on the other hand, was the tempest. He symbolised the coming flood'. ${ }^{91}$ Aldred's dichotomy, between Marx the real theoretician and Bakunin the soul of socialism, was echoed in other assessments. He judged the reformism of Kautsky and Liebkecht, the architects of the policy of political action, by the standards of their theory, quoting their own youthful critiques of parliamentarism against them. ${ }^{92}$ Anarchists, on the other hand, were assessed with reference to their personal talents and virtues and/or by their mistaken attempts to elaborate an anarchist theory. ${ }^{93}$ For example, taking 
issue with Kropotkin once more, Aldred questioned his identification of 'Locke, the timid, and Godwin, the Whig' as the fathers of anarchism. This history of anarchist ideas simply missed the point: what was important in anarchism was what individuals did, not what they thought. Aldred used measures of action to chart his alternative story of British anarchist traditions. In it Richard Carlisle, the early nineteenth-century freethinker, 'whose reward for clear thinking was imprisonment' was the real father of British anarchism. Godwin had no claim whatsoever since he was 'but a politician for all practical purposes' and 'a gentleman'. ${ }^{94}$ Admittedly, Aldred also linked failures of social democracy to Marx's personal weakness. He described Marx as an authoritarian who 'slandered Bakunin' and whose 'personal vanity and domination detract seriously from his claim to our love as a man and a comrade'. ${ }^{95}$ But given Aldred's assumptions about Marx's theoretical standing, this claim merely reinforced his leading idea that the anarchists' main role was to stand out against the Marxists' corruption of their own doctrine - to inoculate it against degeneration into social democracy - it was not to challenge that doctrine with a distinctive philosophy of their own.

One of the peculiarities of this argument is that it casts Bakunin, famous for his desire to abolish God, as a latter-day Jesus: a rebel who gave his life, through constant rebellion, in service to others. As Caldwell notes, 'the mighty Russian' and the 'gentle Nazarene' enjoyed equal status in Aldred's 'humanist pantheon'. ${ }^{96}$ Using Bakunin to bridge the gap between anarchism and Marxism, Aldred suggested that it was the space left in socialism for religion - voluntary service in the name of brotherhood - that anarchism filled. 


\section{Evaluating Aldred}

Aldred's understanding of communism was based on three claims: first that the Marxism of the Second International and, later, of the Stalinist Soviet Union had nothing to do with Marx's ideas and were outgrowths of the personal authoritarianism - or what he called the human egoism - of Marx; second, that anarchists - the Bakuninists, at least - were the activists that the Marxists ought to have been; and third, that the anarchists added nothing of theoretical importance to left criticism. All of these claims are contestable and the last has been fiercely rejected: anarchists have often explained the invisibility of anarchism as a measure of the success with which nonanarchists have appropriated anarchist ideas. George Woodcock adopted this approach when he criticised Chomsky for inventing 'libertarian communism' as a Marxist cover to steal the anarchists' clothes. ${ }^{97}$ Nevertheless, some of Aldred's ideas chime in with contemporary anarchist thinking. His treatment of Marx is similar to a distinction that John Clark has since articulated. Clark distinguishes between two aspects of Marx's thought, one he calls the 'part ... most relevant to his dispute with Bakunin, and which ... has exerted the greatest influence on history' and the other which 'one might well wish to have been of more historical importance'. 98 Some anarchists have even echoed Aldred's much more contentious suggestion, that anarchists have been the practitioners of socialism rather than the theorists. In 1968 - a moment of anarchist revival - Cohn-Bendit was significantly identified as the student movement's prime personification; Daniel Guérin described '"Dany"' as the outstanding spokesman of '68 because, unlike his brother Gaby, he was 'no 
anarchist theoretician' but someone in whom the 'libertarian fire' blazed 'in the highest degree'. ${ }^{99}$ Recently Graeber and Grubacic have argued that this 'fire' is still considered to be anarchism's most distinctive contribution to socialism. In a discussion of '"small-a anarchists"' they note:

Marxism, then, has tended to be a theoretical or analytical discourse about revolutionary strategy. Anarchism has tended to be an ethical discourse about revolutionary practice. As a result, where Marxism has produced brilliant theories of praxis, it's mostly been anarchists who have been working on the praxis itself. ${ }^{100}$ It seems unlikely that the continuing popularity of this idea owes much to Aldred's influence. Nevertheless, his early formulation of the relationship usefully highlights its flaws. One important weakness of Aldred's ideological re-packaging of late nineteenth and early twentiethcentury debates was his assumption of theoretical cohesion amongst opponents of social democracy. The idea that the anarchists were Marx's rightful heirs coupled with the claim that the relevant distinction between anarchists and Marxists turned on questions of practice blinded him to the specificity of his own theoretical position. It also convinced him that anarchist critiques of the state were irrelevant: they could be subsumed into an analysis of class power and bureaucracy and grounded in a theory of historical materialism. Aldred conceded that Bakunin's warnings about the rise of authoritarian communism had been ridiculed. Unfortunately, because he had already decided that Bakunin's significance lay solely in the strength of his convictions, he was not interested in interrogating the theoretical basis of these claims. Instead 
he argued that anarchism offered no solutions to socialists. Even if this was true, the memory of the anarchist critiques was surely worth preserving. Cohn-Bendit clearly thought so when he accused Lenin of 'failing to transcend the organizational level of the bourgeoisie. ${ }^{101}$

A second weakness of Aldred's bridge building was that it was shaped by a conviction that it is possible to establish the provenance of ideas in ways that the history of socialist ideas does not support. Since Aldred's time, different terms have been chosen for the bridge: libertarian communism and communist-egoism are two examples. But the process of bridge building tends to follow Aldred's model. It is likely that Aldred would have been baffled by the current terms of anarchist debate and that he would have questioned the point of sorting anarchists into exclusive, self-contained 'individualist', 'social anarchist' or 'classstruggle' groupings. Having attempted to bring Nietzsche and Kropotkin together, he would have rejected the claim that questions of organisation are somehow un-anarchist, regressive 'imports' from Marxism. It seems likely that he would also have dismissed the counter-claim that a defence of individualism points only to a childish fondness for rebellion and/or that it places advocates beyond the anarchist tradition. ${ }^{102}$ Aldred's socialist theory might not have been persuasive, yet his efforts to engage with and synthesise complex currents of thought helps to highlight the range and diversity of the influences active in pre-war radical and revolutionary circles. Whilst the drift of socialism towards parliamentarism and later Sovietism helps explain his eagerness to bridge the gap between anarchism and Marxism, the ideological 
classification that he devised belied the genuinely rich, synthetic quality

of his thinking and masked the anarchist critique of social democracy.

The disappointment of Aldred's work is not that he attempted to bridge

the gap in socialist traditions, but that he failed to acknowledge the value

of anarchism's theoretical contribution.

Acknowledgements: I would like to thank Trevor Bark, Rory Beaton, Carl Levy and Alex Prichard and Sureyyya Turkeli for encouragement and comments on earlier drafts of the paper. I am also grateful to JPI's two reviewers.

${ }^{1}$ For example, Stuart Christie cites him as an important early influence. Christie, 'Building a Library: Anarchy', Independent on Sunday, 24 July 2005,

http://findarticles.com/p/articles/mi qn4159/is 20050724/ai n14806090 accessed 20 May 2008.

${ }^{2}$ N. Walter, 'Guy A. Aldred (1886-1963)', The Raven, 1 (1) 1986, p. 82.

${ }^{3}$ A. Meltzer, I Couldn't Paint Golden Angels (Edinburgh/Oakland Ca.: AK Press, 1996) ch.

3 accessible at http://www.spunk.org/texts/writers/meltzer/sp001591/angels3.html

${ }^{4} \mathrm{G}$. Aldred, Dogmas Discarded, part 1 in Essays in Revolt (hereafter ER) 2 volumes (Glasgow: Strickland Press, 1940), p. 13. For Aldred's life, see also J. T. Caldwell, Come Dungeons Dark: The Life and Times of Guy Aldred, Glasgow Anarchist (Barr, Ayrshire: Luath Press, 1988).

${ }^{5}$ Aldred, ibid., p. 25.

${ }^{6}$ The relationship is discussed in G. Frost, 'Love Is Always Free: Anarchism, Free Unions and Utopianism in Edwardian England', Anarchist Studies, vol. 17 (1), 2008, pp. 73-94.

${ }^{7}$ G. Aldred, 'The Freewoman', The Herald of Revolt, vol. 2 (3), March 1912, p. 17.

8 J. Caldwell, A Tribute to Guy Alfred Aldred, (Hobnail Press, 2006), n.p.

${ }^{9}$ G. Aldred, 'The Malatesta Outrage', The Herald of Revolt, vol. 2 (6) June 1912, p. 58.

${ }^{10}$ Aldred identified himself as a critical follower of Morris. See Pioneers of Anti-

Parliamentarism in ER, pp. 11-20. Only a year before William Morris's death H.B. Samuels argued that 'communism is, as yet, not generally understood, even by many who are

supposed to worship that ideal'. He described it as 'a condition of society where there shall be perfect freedom in the economical and social relations of life ... [and] the extinction of the institution or idea of "private property"'. Samuels, A Contribution to Communism (London: William Reeves, 1895), pp. 3-4.

${ }^{11} \mathrm{G}$. Aldred, Studies in Communism in ER, p. 4.

${ }_{13}^{12}$ Aldred, Dogmas Discarded, part 1, op. cit., p. 9.

${ }^{13}$ Aldred, ibid., part 2, p. 25.

${ }_{14}^{14}$ Aldred, ibid., part 1, p. 9.

${ }^{15}$ Aldred, ibid., part 1, p. 18.

${ }_{17}^{16}$ Aldred, ibid., part 1, p. 40.

${ }_{17}^{17}$ Aldred, ibid., part 2, p. 28.

${ }^{18}$ Aldred, ibid., part 1, p. 43.

${ }^{19}$ Aldred, ibid., part 2, p. 19.

${ }_{21}^{20}$ Aldred, ibid., part 1, p. 34.

${ }^{21}$ Aldred, ibid., part 1, p. 40.

${ }^{22}$ Aldred, ibid., part 1, p. 13.

${ }^{23}$ Aldred, ibid., part 2, p. 45; part 1, p. 23.

${ }_{25}^{24}$ Aldred, ibid., part 1, p. 10.

${ }^{25}$ Aldred, ibid., part 2, p. 43. 
${ }^{26}$ Aldred, ibid., part 1, p. 18.

${ }^{27}$ Aldred, Pioneers of Anti-Parliamentarism, op. cit., p. 13.

${ }^{28}$ Aldred, Studies in Communism, op. cit., p. 33.

${ }^{29}$ Aldred, ibid., p. 24.

${ }^{30}$ Aldred, ibid., p. 24.

${ }^{31}$ Aldred, ibid., p. 18.

${ }^{32}$ Aldred, ibid., p. 19.

${ }^{33}$ Aldred, ibid., p. 33.

${ }^{34}$ Guy Aldred, 'Our Glasgow Lectures', The Herald of Revolt, vol. 2 (9), September 121912, p. 95.

${ }^{35}$ Aldred, Dogmas Discarded, part 2, op. cit., p. 58.

${ }^{36}$ Aldred, ibid., p. 59.

${ }^{37}$ Aldred, Pioneers of Anti-Parliamentarism, op. cit. p. 16.

${ }^{38}$ Aldred, Dogmas Discarded, part 2, op. cit., p. 26.

${ }^{39} \mathrm{G}$. Aldred, Socialism and Parliament, part 2 in ER vol. II, p. 45.

${ }^{40}$ Aldred quoted Huxley's remark that 'anarchy may be the highest conceivable grade of perfection of social existence' forgetting to note that Huxley concluded the discussion by declaring anarchy a sham and an illusion. See T.H. Huxley, 'Government: Anarchy or Regimentation', 1890, at http://aleph0.clarku.edu/huxley/CE1/G-AR.html

${ }^{41}$ Aldred, Dogmas Discarded, part 2, op. cit., p. 38; Aldred, Studies in Communism, op. cit., p. 6.

${ }^{42}$ Aldred, Studies in Communism, op. cit., p. 7.

${ }^{43}$ Aldred, ibid., p. 7.

${ }^{44}$ Aldred, ibid., p. 7.

${ }^{45}$ Aldred, ibid., p. 21

${ }^{46}$ Aldred, ibid., p. 21.

${ }^{47}$ Guy Aldred, 'Friedrich Nietzsche' in John Moore and Spencer Sunshine (eds), I Am Not Man, I Am Dynamite! Friedrich Nietzsche and the Anarchist Tradition (New York: Autonomedia, 2004), p. 9.

${ }^{48}$ Aldred, ibid., p. 10.

${ }^{49}$ Orage is discussed in T. Steele Alfred Orage and the Leeds Arts Club 1893-1923, (Aldershot: Scholar Press, 1990). For Marsden see L. Garner A Brave and Beautiful Spirit: Dora Marsden 1882-1960, (Aldershot: Gower Publishing, 1990); B. Clarke Dora Marsden and Early Modernism: Gender, Individualism, Science, (Ann Arbor University of Michigan Press, 1996); and L. Delap The Feminist Avant-Garde: Translatlantic Encounters of the Early Twentieth Century, (Cambridge: Cambridge University Press, 2007).

${ }^{50}$ Aldred, Nietzsche, op. cit., p. 11.

${ }^{51}$ Two short pamphlets give a useful overview: J.T. Caldwell \& M. Shipway An Introduction to Guy Alfred Aldred and Anti-Parliamentary Communist Federation, (Hobnail Press, 2006); B.Jones, Anti-Parliamentarism and Communism in Britain 1917-21, (Pirate Press, 1991).

${ }^{52}$ G. Aldred, Studies in Communism in ER, p. 4.

${ }^{53}$ P. Thomas, Karl Marx and the Anarchists (London: Routledge \& Kegan Paul, 1980) p. 317.

${ }^{54}$ G.D.H. Cole, A History of Socialist Thought, vol. III part 1, The Second International 1889-1914, (London: St. Martins Press, 1967) pp. xv; 26.

${ }^{55}$ E. Marx-Aveling, 'A Note on the International and the British Trade Union Congresses', Justice, 19 September 1896, p. 6. The expulsion captured a range of revolutionary socialists, some of whom did not self-identify with anarchism.

${ }^{56}$ D. Nienwenhuis, Le Socialisme En Danger (Paris: P-V Stock, 1897), p. 45.

${ }^{57}$ A. Hamon, Le Socialisme et le Congrès de Londres (Paris: P-V Stock, 1897), pp. 7-9.

${ }^{58}$ Hamon, ibid., p. 187.

${ }^{59}$ Justice, 29 July, 1896.

${ }^{60} \mathrm{~J}$. Watts, 'An Appeal for the Anarchists', Justice, 8 August 1896, p. 3.

${ }^{61}$ Aldred, Dogmas Discarded, part 2, op cit., p. 52-3.

62 J.M. O'Fallon, 'Social Democratic Federation Socialism v. Anarchism and Its Sympathisers', Justice, 5 September 1896, p. 4.

${ }_{63}$ J.M. O'Fallon, 'Anarchy and Anarchism', Justice, 19 September 1896, p. 2.

${ }^{64}$ Justice, 'Our Enemies the Anarchists', 5 September 1896, p. 1. 
${ }^{65}$ G. Pleckanov [Plechanoff], Anarchism and Socialism, trans. E. Marx-Aveling (Chicago:

Charles Kerr, n.d.).

${ }^{66}$ W. Liebknecht, 'Our Recent Congress', Justice, 15 August 1896, p. 4.

${ }^{67} \mathrm{~J}$. Robins, 'Plechanoff Answered', The Torch, 18 April 1895

${ }^{68}$ W. Liebknecht, 'Our Recent Congress', op. cit.

${ }^{69}$ Justice, 'An Anarchist Messiah', 14 November 1896, p. 1.

${ }^{70}$ E.B. Bax, Essays in Socialism (London: E. Grant Richards, 1907), pp. 64-5; E.B. Bax \& J.

Haim Levy, Socialism and Individualism (London: Personal Rights Association, n.d.), p. 33.

${ }_{72}^{71}$ A.B. 'Anarchism in Practice', Justice, 5 December 1896, p.2.

${ }^{72}$ Freedom September 1890, p. 35.

${ }^{73}$ E. Malatesta, 'Report of the Holborn Town Hall Meeting', Freedom supplement, AugustSeptember 1896, p. 98.

${ }^{74}$ C.T. Quinn, 'Anarchist Organization', The Torch, August 1894, p. 2.

${ }^{75}$ E. Reclus, 'Report of the Holborn Town Hall Meeting', Freedom supplement, AugustSeptember 1896, p. 97.

${ }^{76}$ J.A. Andrews, 'Anarchist Organisation' Freedom supplement, July 1896, p. 87.

${ }_{78}^{77}$ W. Tcherkesov, 'Socialism or Democracy', Freedom supplement, July 1895. pp. 18-19.

${ }^{78}$ W. Tcherkesov, 'Frederick Engels', Freedom supplement, September 1895, p. 39.

${ }^{79}$ Aldred, Pioneers of Anti-Parliamentarism, op. cit., p. 74.

${ }^{80}$ Guy Aldred, Bakunin in ER vol. II, , p. 47.

${ }^{81}$ D. Cohn-Bendit, Obsolete Communism the Left-Wing Alternative, trans. A. Pomerans (London: André Deutsch, 1968), p.18.

${ }^{82}$ Aldred, Bakunin, op. cit., p. 47.

${ }^{83}$ Aldred, ibid., pp. 43-4

${ }^{84}$ Aldred, Pioneers of Anti-Parliamentarism, op. cit., p. 54.

${ }^{85}$ Aldred, ibid., p. 26

${ }^{86}$ Aldred, Bakunin, op. cit. p. 43.

${ }^{87}$ Aldred, Pioneers of Anti-Parliamentarism, op. cit., p. 31.

${ }^{88}$ Guy Aldred, 'Parliament and the Commune' The Herald of Revolt, vol. 2 (1), January 1912 , p. 3.

${ }^{89}$ Aldred, Bakunin op. cit., p. 46.

${ }^{90}$ Aldred, ibid., p. 51.

${ }^{91}$ Aldred, ibid., p. 51.

${ }^{92}$ Aldred, Studies in Communism op. cit., p. 12; Socialism and Parliament part 1, op. cit., p. 15.

${ }_{93}$ Aldred, Dogmas Discarded part 2., op. cit., p. 53.

${ }^{94}$ Aldred, Socialism and Parliament part 1, op. cit., p. 47.

${ }^{95}$ Aldred, Bakunin op.cit., p. 36.

${ }^{96}$ Caldwell, 'Guy Aldred \& the background to the Anti-Parliamentary Communist Federation',

in Caldwell \& Shipway An Introduction to Guy Alfred Aldred and the Anti-Parliamentary

Communist Federation, op. cit. p. 2.

97 G. Woodcock, 'Chomsky's Anarchism' in Anarchism and Anarchists (Kingston, Ontario: Quarry Press, 1992), p. 228.

98 J. Clark, 'Marx, Bakunin and Social Revolution' in The Anarchist Moment (Montreal: Black Rose, 1984), p. 89.

${ }_{99}$ D. Guérin, Anarchism, trans. M. Klopper (New York: Monthly Review Press, 1970), p.158.

${ }^{100}$ D. Graeber and A. Grubacic, 'Anarchism or the Revolutionary Movement for the $21^{\text {st }}$ Century', http://www.zmag.org/content/showarticle.cfm?ltemID=4796, accessed 9 February 2008.

${ }^{101}$ Cohn-Bendit, Obsolete Communism, op. cit., p. 216.

${ }^{102}$ For a discussion see M. Bookchin Social Anarchism or Lifestyle Anarchism: An Unbridgeable Chasm (Edinburgh/Oakland Ca.: AK Press, 1995) and B. Black, Anarchy After Leftism (Columbia, Missouri: C.A.L.Press, 1997). M. Schmidt and L. van der Walt present a statement of class struggle anarchism in Black Flame: The Revolutionary Class Politics of Anarchism and Syndicalism (Edinburgh/Oakland Ca.: AK Press, 2009). 